\title{
Exocrine Pancreatic Cancer pM1 TNM
}

\section{Finding v6}

National Cancer Institute

\section{Source}

National Cancer Institute. Exocrine Pancreatic Cancer pM1 TNM Finding v6. NCI

Thesaurus. Code C60954.

Exocrine pancreatic cancer with distant metastasis. (from AJCC 6th Ed.) 